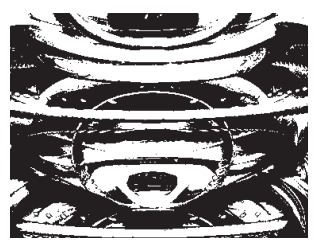

\title{
RELATIONSHIP BETWEEN PERSONALITY AND ADOLESCENT DRUG USE: EFFECTS OF SUBSTANCE ABUSING PEERS AND GENDER
}

Vlado ŠAKIĆ, Ivana VRSELJA, Anja WERTAG Institute of Social Sciences Ivo Pilar, Zagreb

UDK: 159.942-053.6:178.8

Izvorni znanstveni rad

Primljeno: 19. 2. 2013.

The goal of this paper was to explore whether sensation seeking and anger exert a direct and/or an indirect effect on adolescent lifetime cannabis and inhalant use through substance abusing peers. In addition, the purpose was to explore whether direct effects of these two personality factors are dependent on gender. Analyzed data were collected in 2012 from 394 students (186 boys, 193 girls, while 15 students didn't indicate their gender), aged between 15 and 17 years. In the case of lifetime cannabis use, mediation analyses showed the significance of the indirect effect of sensation seeking on this drug type use through substance abusing peers. Likewise, it was shown that sensation seeking and anger both exert direct effect on this drug type, but independently of gender. In the case of lifetime inhalant use, two personality factors do not exert indirect nor direct effect on this drug type use. In addition, these direct effects are not dependent on gender. Data presented in this paper elucidate risk pathways to cannabis and inhalant use, considering some possible differences between these risk pathways.

Keywords: sensation seeking, anger, peers, cannabis, inhalants 
Available data show that drug use among Croatian adolescents is extensive. According to the results of the European School Survey Project on Alcohol and Other Drugs (ESPAD) for 2011, out of 36 European countries, Croatia has the highest proportion of students who have tried inhalants at least once in their life. More precisely, $28 \%$ of all students reported using an inhalant at least once (31\% of girls, compared to $25 \%$ of boys). Marijuana use, which is usually the most common among illicit substances, was reported by $18 \%$ of all Croatian students in the ESPAD research ( $21 \%$ of boys, compared to $14 \%$ of girls).

Adolescent drug use has numerous negative consequences on developmental outcomes. Therefore, it is extremely important to study development and risk factors for this kind of behavior. Research shows that there are numerous and varied factors which influence drug use. Hawkins, Catalano, and Miller (1992) divide these risk factors into two categories. The first category refers to societal and cultural factors that provide legal and normative expectations for behavior. The second category includes intrapersonal and interpersonal factors (families, school classrooms, and peer groups). A comprehensive review of these factors is beyond the scope of this paper. Given that the association of individual factors with drug use is of primary interest in this paper, we will dedicate more attention to this category of risk factors.

Most of the personality traits do not show strong links to drug use (Oetting \& Lynch, 2003), apart from sensation seeking (Donohew et al., 1999; Yanovitzky, 2005) and anger (Oetting \& Beauvais, 1988; Swaim, Oetting, \& Beauvais, 1989; Nichols, Mahadeo, Bryant, \& Botvin, 2008). According to Zuckerman (1994), sensation seeking is a biologically based trait that can be defined as the seeking of varied, novel, complex, and intense sensations and experiences, along with the willingness to take physical, social, legal, and financial risks for the sake of such experiences. Studies have consistently shown that males score higher on sensation seeking than females do (Zuckerman, 1994, 1996; Rosenblitt, Soler, Johnson, \& Quadagno, 2001) and that males are more prone to risk-taking behavior (Arnold, Fletcher, \& Farrow, 2002; Rolison \& Scherman, 2002). Moreover, studies show that sensation seeking intensifies in adolescence (Hampson, Andrews, \& Barckley, 2008), which may explain increment in drug use in this period (Yanovitzky, 2005). Yanovitzky (2005) states that there are three explanations in the literature regarding the association between sensation seeking and adolescent drug use: 1) since drug use involves taking illegal risks, high sensation-seekers (HSS) find it stimulating, 2) HSS underestimate the risks associated with drug use, 
DRUŠ. ISTRAŽ. ZAGREB GOD. 22 (2013), BR. 4 STR. $651-669$

ŠAKIĆ, V., VRSELJA, I. WERTAG, A RELATIONSHIP. and therefore do not consider drug use as a risky behavior and 3) HSS use drugs in order to experience the neurological stimulation that such substances provide. Besides scoring higher on sensation seeking, males are generally more prone to exhibiting deviant behavior than females, and this behavior is more pronounced in men. Some authors (e.g. Newcomb \& McGee, 1991; Oetting, Deffenbacher, \& Donnermeyer, 1998) consider deviant behavior as a reflection of sensation-seeking tendencies, which, in turn, have been associated with men's testosterone levels.

Regarding trait anger, Spielberger et al. (1985) define it as a relatively stable and enduring personality trait which refers to proneness to perceive situations as anger provoking and to respond with feelings of annoyance, irritation, or fury. While there are some gender differences in modes of anger expression (e.g., discussing anger and expressing it somatically, with women scoring higher on both), it was shown that men and women do not differ in trait anger (e.g., Thomas \& Williams, 1991; Simon \& Lively, 2010). As in the case of sensation seeking, it is generally shown that this trait is associated with substance use, especially alcohol (Oetting \& Lynch, 2003). In addition, results of previous research (e.g. Colder \& Stice, 1998) showed that gender moderates effects of anger on substance use so that proneness to anger and frustration was associated with higher levels of substance use for females, but not for males. The reason for that may lie in the fact that boys are $\mathrm{u}-$ sually socialized to express angry feelings, whereas girls are socialized to inhibit and constrain the expression of angry feelings, which may produce emotional distress, and lead to high levels of substance use for girls.

Apart from correlation with drug use, these two personality traits consistently show a correlation with drug using or deviant peers (e.g., Swaim et al., 1989; Yanovitzky, 2005, 2006), and the association with drug using peers is one of the strongest risk factors for drug use among adolescents and youth. These findings indicate that there is a possibility that sensation seeking and anger do not contribute to drug use directly, but rather indirectly through association with peers who are drug users. These relationships are introduced in peer cluster theory (Oetting \& Beauvais, 1987) and more recent primary socialization theory (Oetting \& Donnermeyer, 1998), which both propose that personality traits do not exert a direct influence on adolescents' drug use, but, in nearly all cases, influence this kind of deviant behavior only indirectly, through its effect on primary socialization sources (i.e. peers, family, and school). More precisely, Oetting and Lynch (2003) stated reasons as to why sensation seeking increases the chances that youth will get involved with drug-using peers: youth high on 
DRUŠ. ISTRAŽ. ZAGREB GOD. 22 (2013), BR. 4, STR. $651-669$

ŠAKIĆ, V., VRSELJA, I., WERTAG, A. RELATIONSHIP. this personality variable find others who also need a high level of stimulation and excitement and form peer clusters with them. The norms of these peer clusters will determine whether the exciting activities they choose will involve drug use. Yanovitzky (2005) found that sensation seeking increased the risk of adolescent drug use not only directly, but also indirectly in a way that high sensation-seeking adolescents tended to associate with deviant peers and initiate discussions with peers that favor drug use. Moreover, Yanovitzky (2006) found that the personality trait of sensation seeking affects alcohol use by college students both directly and indirectly, by increasing their susceptibility to peer pressure to consume alcohol. Regarding anger, reasons why angry youth associate with drug-using peers include aggressive acts in previous peer interactions, which lead to bonding problems with prosocial peers, and conflicts with parents and school officials that lead to bonding problems in those interpersonal relationships (Oetting \& Lynch, 2003). Angry youth may tend to find other angry youth and form peer clusters with them. In such clusters, there is increased likelihood that their members reinforce each other's expression of anger. These shared feelings can result in drug use, especially if youth consider this kind of behavior as rebellious and authority-challenging (Oetting \& Lynch, 2003). However, Swaim et al. (1989) reported that anger exerts both direct and indirect effect on drug use through peer drug association, and that this holds true for both male and female students.

Previous research did not focus on exploring whether the relationship between personality variables of sensation seeking and anger and substance abusing peers is differentially important regarding the type of the used drug. Since involvement in different forms of drugs may have different explanations and underlying roots, we will explore these relationships separately for two types of drugs in this paper. One type of the studied drug is cannabis, because it is usually by far the most common used illicit drug among adolescents. Since results of the ESPAD research show that inhalant use is even more prevalent among Croatian students than the use of cannabis, we sought to explore the relationship among studied variables in the context of this drug as well. In addition, since previous research did not focus on exploring whether the direct effects of personality variables on cannabis and inhalants use are moderated by gender, we sought to explore this as well.

Based on the previous research (i.e. Yanovitzky, 2005, 2006; Swaim et al., 1989), we hypothesized that personality factors of sensation seeking and anger have both direct and indirect effects on cannabis and inhalants use. In terms of indirect effects of personality factors, we hypothesized that more pro- 
DRUŠ. ISTRAŽ. ZAGREB GOD. 22 (2013), BR. 4 STR. $651-669$

ŠAKIĆ, V., VRSELJA, I. WERTAG, A RELATIONSHIP.

\section{METHOD}

\section{Sample}

\section{Procedure}

nounced sensation seeking and anger predict association with greater number of substance abusing peers, which, in turn predict more frequent cannabis and inhalants use. Furthermore, it is hypothesized that both sensation seeking and anger exert direct effect on cannabis and inhalants use after controlling for the effect of substance abusing peers. Finally, based on the previous research (e.g. Colder \& Stice, 1998; Swaim et al., 1989) and considerations (e.g. Newcomb \& McGee, 1991; Oetting et al., 1998) we hypothesized that the magnitude of these direct effects is dependent on gender. Specifically, we hypothesize that, after controlling for effects of substance abusing peers, more pronounced sensation seeking is related to more frequent cannabis and inhalants use in boys, and that more pronounced anger is related to more frequent cannabis and inhalants use in girls.

The sample consisted of 394 students (186 boys, 193 girls, while 15 students didn't indicate their gender) from three public high schools in Zagreb, Croatia. The mean age was 16 years $(\mathrm{SD}=0.78)$. Eighty-six percent of respondents lived in intact families, while $14 \%$ were from a broken family. Sixty-seven percent of respondents attended four-year vocational schools and grammar schools or "gymnasiums", while 33\% attended three-year vocational schools.

Almost half of the respondents' parents had at least a secondary school education (48.4\% mothers and $48.3 \%$ fathers). Two-thirds of the respondents (67.2\%) come from families with an average family economic status.

Data used for this paper is derived from a broader survey conducted by the Institute of Social Sciences Ivo Pilar between May and June 2012. The research was conducted in accordance with the Ethical Code of Research with Children in Croatia (Dulčić, Ajduković, \& Kolesarić, 2003). The respondents were assured that their participation in this research is voluntary and anonymous and that all information provided is confidential. Furthermore, they were assured that the obtained data will be processed only at the group level. After providing passive informed consent form from their parents, respondents signed an informed consent form and then completed the questionnaire. The questionnaire was administered in classrooms during regular school hours by a trained researcher. The data collection session lasted approximately 30 minutes. 
Respondents were given instructions and any additional questions pertaining to the study were addressed.

\section{Measures}

Lifetime cannabis use was assessed with one item taken from the Youth Self-Reported Risk and Delinquent Behavior Questionnaire (Ručević, Ajduković, \& Šincek, 2009). This item measures lifetime marijuana or hashish use on a five-point scale from 0 (never) to 4 (21 or more times). Because distribution of this variable is highly skewed, the obtained answers were dichotomized ( 0 - never, 1 - one or more times).

Lifetime inhalant use was measured with one item taken also from the Youth Self-Reported Risk and Delinquent Behavior Questionnaire (Ručević et al., 2009). Participants gave their answers on a scale from 0 (never) to 4 (21 or more times). The obtained answers on this variable were dichotomized as well due to its' highly skewed distribution, with 0 indicating never, and 1 one or more times.

Sensation seeking was measured with Form V of the Sensation Seeking Scale (SSS; Zuckerman, Eysenck, \& Eysenck, 1978). This is a forced-choice questionnaire consisting of 40 items. Each of these items represents a tendency towards sensation seeking propensity, and has two statements (marked A and B) indicating higher or lower sensation seeking. The SSS consists of four subscales, with 10 items on each subscale: Thrill and Adventure Seeking (TAS; e.g., "I would like to try bungee jumping"), Disinhibition (DIS; e.g., "I would love to have new and exciting experiences, even if they are illegal"), Experience Seeking (ES; e.g., "I would like to explore strange places"), and Boredom Susceptibility (BS; e.g., "I get restless when I spend too much time at home"). A total score on this scale is used in this study, which is obtained by means of summing items on all four subscales. This score ranges from 0 to 40, with a higher one indicating more sensation seeking. The scale has acceptable internal reliability, which is $\alpha=0.74$.

Substance abusing peers was measured with four items taken from Association with Deviant Peers Questionnaire (Vrselja, unpublished manuscript). These items measure the number of friends that abuse substances on a scale from 1 (none) to 5 (all of them). Specifically, they include the number of friends who were at school under the influence of alcohol or some drug, selling drugs, used drugs (marijuana, ecstasy, cocaine, hashish, heroin, LSD etc.), and got drunk (with bear, wine, vod$\mathrm{ka}$, whiskey, etc.). The total score was calculated as an average score on these four items, with a higher score indicating more substance abusing friends. Reliability coefficient alpha was acceptable, i.e., $\alpha=0.78$. 
DRUŠ. ISTRAŽ. ZAGREB GOD. 22 (2013), BR. 4 STR. $651-669$

ŠAKIĆ, V., VRSELJA, I., WERTAG, A RELATIONSHIP.
Trait anger was measured with the anger subscale of the Buss and Perry Aggression Questionnaire (1992). This subscale consists of seven items, e.g., "When frustrated, I let my irritation show" and "Some of my friends think I am a hothead." Respondents indicated their answers on a five-point scale (1 - extremely uncharacteristic of me, 5 - extremely characteristic of me). The total score on this scale was formed by means of summing each item, with a higher score indicating more pronounced trait anger. Reliability coefficient Cronbach's alpha was acceptable, i.e., $\alpha=0.75$.

Control variables. Other variables investigated in this study refer to those shown in the literature to be important risk factors for the outcomes of interest. These include older adolescent age (Gruber, 2001), broken families (Needle, Su, \& Doherty, 1990), and child-parent disagreement (Resnick et al., 1997). Age was measured as the current age in years at the time of questionnaire administration. Family structure was assessed with one item on which respondents were asked to indicate the marriage status of their parents according to four categories: married, divorced, cohabitation, and widowed father (or mother). Answers were dichotomized, in a way that divorced and widowed father (or mother) were coded as 1 (broken family), and married and cohabitation were coded as 2 (intact family). Child-parent disagreement was measured with two items: "How do you get along with your father/mother?". Respondents indicated their answers on a five-point scale from 1 (not at all) to 5 (completely). The obtained answers on both items were then recoded so that lower results indicate lower disagreement. These two items correlate significantly, i.e., $r=0.39(p<0.01)$. The total score on child-parent disagreement was formed by averaging the responses across these two items, with a higher score indicating higher child-parent disagreement.

\section{Strategy for analysis}

First, basic descriptive and intercorrelation data were analyzed. To test indirect and direct effects of personality on drug use, we used the PROCESS macro developed by Hayes (2013). The procedure outlined by these authors has recently been recommended for testing mediation because it provides higher statistical power than the popular causal steps approach by Baron and Kenny (1986). Unlike the causal steps approach, Preacher and Hayes's (2008) method does not require the existence of significant correlation between the independent variable and the dependent variable. In addition, in contrast to the causal steps approach, this method provides data relevant to testing size and significance of an indirect effect. Signifi- 
DRUŠ. ISTRAŽ. ZAGREB GOD. 22 (2013), BR. 4, STR. 651-669

ŠAKIĆ, V., VRSELJA, I., WERTAG, A. RELATIONSHIP.. cance testing is based on a bootstrapping resampling strategy. In our analyses, we used a conventional number $(5,000)$ of bootstrap resamples with a $95 \%$ confidence interval (CI). If zero is not in CI, we can say with $95 \%$ confidence that the indirect effect is statistically significant (Preacher \& Hayes, 2008; Shrout \& Bolger, 2002).

In this paper, we tested four indirect effects models with the same assumed mediator (substance abusing peers). The first two models refer to the indirect effect of sensation seeking on cannabis and inhalant use separately, while the second two models refer to the indirect effects of anger on the use of these two drugs. In addition, in every model we tested whether direct effect of personality on drug use is dependent on gender. The effects of age of the respondent, family structure and the level of disagreement with their parents were controlled in every step of the analysis. It is important to mention that while the indirect and direct effects of one personality variable were examined, the second one was treated as control.

\section{RESULTS}

\section{Descriptive analysis}

As it can be seen in Table 1, the mean age in our sample is 16, and $49 \%$ of our sample are girls. The majority $(86.30 \%)$ of respondents come from families with two parents, and on average, they get along with their parents on a scale from very good to excellent. Compared to the theoretical averages on the scales, the reported sensation seeking and anger was average in our sample as well. Respondents associated with substance abusing peers in a range from one to a few. More than one quar-

(1) TABLE 1

Descriptives for study variables ter of respondents reported using marijuana or hashish at least once in their life, while $15.70 \%$ of them tried using inhalants at least once in their life.

\begin{tabular}{lrrrrr}
\hline & & & & & Range \\
\cline { 5 - 6 } & $\mathrm{N}$ & $\mathrm{M}(\%)$ & $\mathrm{SD}$ & Expected & Actual \\
\hline Gender & 379 & $49 \%$ females & - & $0-1$ & $0-1$ \\
Age & 386 & 16.11 & 0.78 & $15-17$ & $15-17$ \\
Family structure & 386 & 86.30 & - & $0-1$ & $0-1$ \\
Child-parent disagreement & 382 & 1.69 & 0.66 & $1-5$ & $1-4$ \\
Sensation seeking & 328 & 20.71 & 5.29 & $0-40$ & $6-32$ \\
Anger & 387 & 19.88 & 5.31 & $7-35$ & $8-33$ \\
Substance abusing peers & 361 & 2.38 & 0.91 & $1-5$ & $1-5$ \\
Lifetime cannabis use & 390 & 26.60 & - & $0-1$ & $0-1$ \\
Lifetime inhalants use & 387 & 15.70 & - & $0-1$ & $0-1$ \\
\hline
\end{tabular}

Note. Ns vary due to occasional missing data. 
DRUŠ. ISTRAŽ. ZAGREB GOD. 22 (2013), BR. 4 STR. $651-669$

ŠAKIĆ, V., VRSELJA, I., WERTAG, A : RELATIONSHIP.

(1) TABLE 2

Intercorrelations between study variables
Table 2 incorporates Pearson's correlation coefficients for all assessed variables. As it can be seen, gender was significantly correlated with sensation seeking and anger, as well as with, lifetime inhalants use, indicating that sensation seeking was more pronounced in the sample of boys, while anger was more pronounced among girls, who also reported more frequent inhalants use than boys. In addition, positive correlations among age and substance abusing peers and age and lifetime cannabis use indicated that older adolescents associated more with substance abusing peers and reported more frequent use of cannabis. Cannabis use was positively correlated with both higher levels of sensation seeking and higher levels of anger, while there were no significant correlations between personality factors and inhalants use. However, both cannabis and inhalants lifetime use were positively correlated with substance abusing peers. Both personality factors were positively intercorrelated, and positively correlated with substance abusing peers. Finally, family structure and child-parent disagreement did not have statistically significant correlates among the assessed variables.

\begin{tabular}{|c|c|c|c|c|c|c|c|c|c|c|}
\hline & & 1 & 2 & 3 & 4 & 5 & 6 & 7 & 8 & 9 \\
\hline 1 & Gender & - & -0.02 & -0.07 & 0.06 & $-0.16^{* *}$ & $0.20 * *$ & -0.09 & -0.10 & $0.11^{*}$ \\
\hline 2 & Age & & - & -0.07 & -0.01 & 0.09 & 0.01 & $0.24^{* *}$ & $* 0.25^{* *}$ & 0.02 \\
\hline 3 & Family structure & & & - & -0.06 & -0.07 & 0.01 & -0.04 & -0.03 & 0.00 \\
\hline 4 & Child-parent disagreement & & & & - & 0.04 & 0.10 & 0.06 & 0.02 & 0.07 \\
\hline 5 & Sensation seeking & & & & & - & $0.18^{* *}$ & * $0.48^{* *}$ & * $0.41^{* *}$ & 0.09 \\
\hline 6 & Anger & & & & & & - & $0.15^{* *}$ & * $0.15^{* *}$ & 0.05 \\
\hline 7 & Substance abusing peers & & & & & & & - & $0.51^{* *}$ & $0.14^{* *}$ \\
\hline 8 & Lifetime cannabis use & & & & & & & & - & 0.05 \\
\hline 9 & Lifetime inhalants use & & & & & & & & & - \\
\hline
\end{tabular}

Note. Gender was coded as male $=0$, female $=1 .{ }^{*} \mathrm{p}<0.05,{ }^{* *} \mathrm{p}<0.01$

\section{Direct and indirect effects of personality on lifetime cannabis and inhalant use}

In order to explain paths involved in indirect and direct effects of investigated personality factors on lifetime cannabis and inhalant use as clearly as possible, we have presented them graphically.

Figure 1 shows the obtained paths in mediation analyses with sensation seeking and anger as the predictor variables and lifetime cannabis use as a criterion variable.

As seen in Figure 1, more pronounced sensation seeking predicted more association with substance abusing peers $(B=0.08$, $p<0.05)$ which, in turn, predicted lifetime cannabis use $(B=1.41$, $\mathrm{p}<0.01)$. Bootstrap analysis showed that the point estimate 
DRUŠ. ISTRAŽ. ZAGREB GOD. 22 (2013), BR. 4, STR. 651-669

ŠAKIĆ, V., VRSELJA, I., WERTAG, A.

RELATIONSHIP...
2 FIGURE 1

Relationship between personality, substance abusing peers, gender and lifetime cannabis use - results of separate analyses for sensation seeking and anger of indirect effect that sensation seeking exerted on cannabis use lies between 0.0628 and 0.1628 . Since zero is not in this interval, we can conclude with $95 \%$ confidence that this indirect effect is significant. As seen from Figure 1, sensation seeking exerted not only an indirect effect on lifetime cannabis use, but also a direct effect. Namely, the results showed that this personality factor remains significant in predicting adolescents' lifetime cannabis use even after controlling for substance abusing peers $(B=0.14, \mathrm{p}<0.05)$. Finally, the results showed that this direct effect is not dependent on gender $(B=-0.73, p>0.05)$. Regarding anger effects, it was shown that this personality factor exerted only direct effect on lifetime cannabis use $(B=0.10$, $\mathrm{p}<0.05)$ in a manner that more expressed anger predicts more frequent lifetime cannabis use. Since this variable doesn't predict association with substance abusing peers, we can conclude that there is no effect to be mediated. In addition, the results showed that direct effect of this personality factor on lifetime cannabis use is not dependent on gender $(B=-0.10, p>0.05)$.

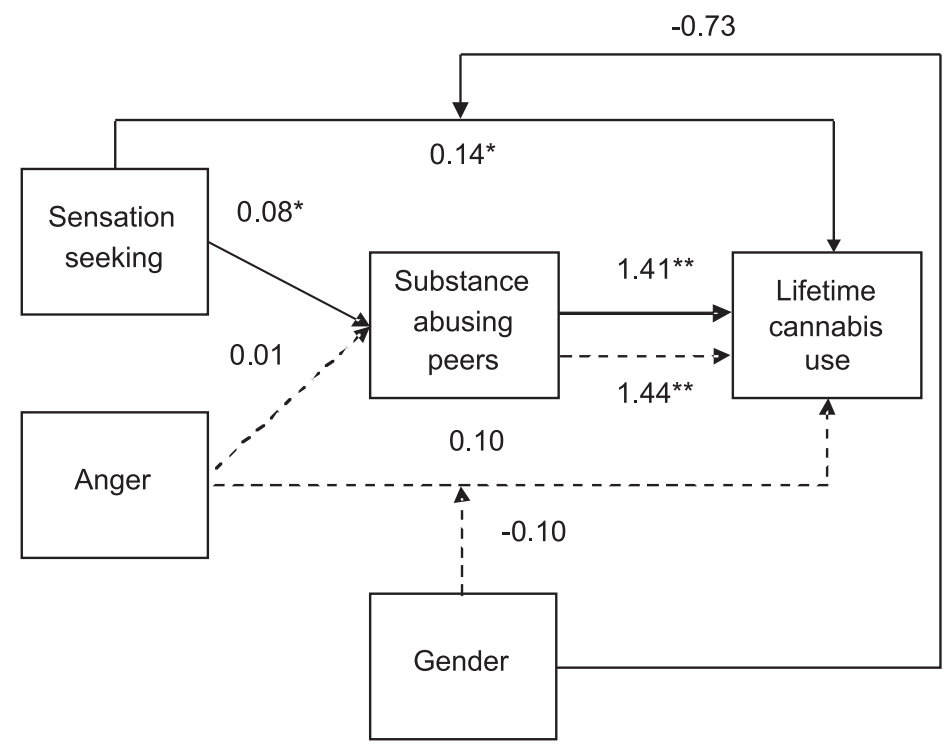

Note. Full lines present paths from sensation seeking to lifetime cannabis use, and dashed lines present paths from anger to lifetime cannabis use. Unstandardized paths coefficients are presented. ${ }^{*} \mathrm{p}<0.05$, ${ }^{* *} \mathrm{p}<0.01$. Nagelkerke $\mathrm{R}^{2}$ for sensation seeking is $0.49(\mathrm{~N}=286)$, and for anger $0.47(\mathrm{~N}=332)$.

Figure 2 shows the obtained paths in mediation analyses with lifetime inhalant use as a criterion variable. As it can be seen, the only significant path in this analysis was the one from sensation seeking to substance abusing peers $(B=0.07, p<0.05)$. 
จ FIGURE 2

Relationship between personality, substance abusing peers, gender and lifetime inhalant use - results of separate analyses for sensation seeking and anger
Therefore, there is no indirect or direct effect of both personality factors on lifetime inhalant use, nor are these personality factors dependent on gender.

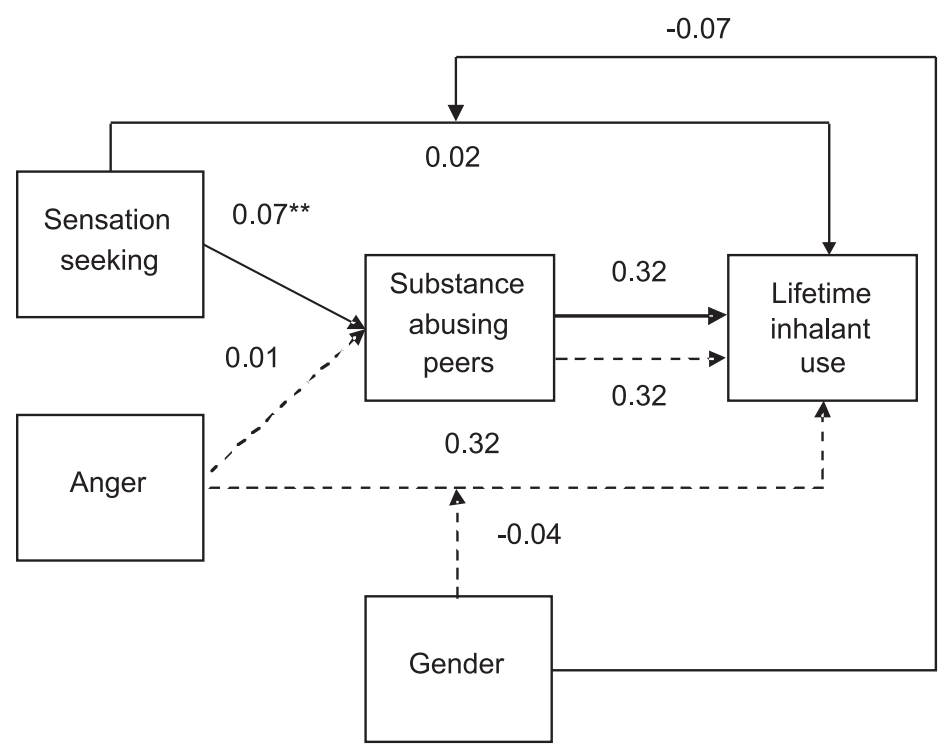

Note. Full lines present paths from sensation seeking to lifetime inhalant use, and dashed lines present paths from anger to lifetime inhalant use. Unstandardized paths coefficients are presented. ${ }^{*} \mathrm{p}<0.05$, ${ }^{* *} \mathrm{p}<0.01$. Nagelkerke $\mathrm{R}^{2}$ for sensation seeking is $0.06(\mathrm{~N}=284)$, and for anger $0.07(\mathrm{~N}=330)$.

\section{DISCUSSION}

The purpose of this study was to explore the existence of direct and/or indirect effects of sensation seeking and anger on adolescent lifetime cannabis and inhalant use through association with substance abusing peers. Likewise, the purpose was to explore whether direct effects of these two personality factors are dependent on gender.

With regard to lifetime cannabis use, the results showed that sensation seeking exerts an indirect effect on lifetime use of this drug. Paths involved in this indirect effect revealed that more pronounced sensation seeking predicted more association with substance abusing peers, which, in turn, predicted lifetime cannabis use. Apart from an indirect effect, the results showed that sensation seeking exerts a direct effect on lifetime cannabis use. These findings are in accordance with our expectations and previous research (e.g. Yankovitzky, 2006, 2005). Although male gender is generally associated with more pronounced sensation seeking and deviant behavior (e.g. New- 
DRUŠ. ISTRAŽ. ZAGREB GOD. 22 (2013), BR. 4, STR. 651-669

ŠAKIĆ, V., VRSELJA, I., WERTAG, A. RELATIONSHIP. comb \& McGee, 1991; Oetting et al., 1998), we did not find the direct effects of this personality factor on cannabis use being dependent on gender. Our finding is in line with some previous research on college and university students in Russia (Knyazev, 2010) and the USA (Zuckerman \& Kuhlman, 2000; Scurlock, 2010). Knyazev, (2010) investigated on a large sample of Russian college and university students if sensation seeking was a predictor of drug use (with this variable being a composite of several items measuring use of various drugs) with gender by personality interaction, and did not find this interaction effect to be significant. On the other hand, similar results were obtained in the USA university samples, where Zuckerman and Kuhlman (2000) investigated possible interactions between gender, personality and risk-taking (including use of various drugs), while Scurlock (2010) investigated whether the interaction of sensation seeking and gender predicted stimulant use. Regarding anger effects, the results of our study showed that this personality factor exerts significant direct but not indirect effect on lifetime cannabis use. Unlike findings related to effects of sensation seeking, these results are not in accordance with our expectations and previous research (e.g. Swaim et al., 1989) which has shown that this personality factor exerts both direct and indirect effect on drug use through association with substance abusing peers. In addition, although the previous research (e.g. Colder \& Stice, 1998) showed that gender moderates effects of anger on substance use, we did not find the direct effects of this personality factor on cannabis use being dependent on gender. These discrepancies may be due to the explored drug type. While in our study the direct and indirect effects of anger were studied separately on cannabis and inhalant use, previous studies investigated these effects on overall drug use (a combination of the use of alcohol, marijuana, cocaine, inhalants, heroin, PCP, LSD etc.).

When it comes to lifetime inhalant use, the results of our study showed that neither sensation seeking, nor anger had a significant indirect effect on the use of this drug type through association with substance abusing peers. Due to the lack of research that has investigated indirect effects of these personality factors on inhalant use, we cannot compare our findings with the findings of previous research. Nevertheless, we can conclude that our findings regarding insignificant indirect effect of both personality factors on lifetime inhalant use are not in accordance with our expectations. One possible explanation for this finding may lie in the used measure of substance abusing peers. Although association with drug abusing peers was shown to be one of the strongest risk factors for drug use among adolescents, we did not find the significant 
DRUŠ. ISTRAŽ. ZAGREB GOD. 22 (2013), BR. 4 STR. $651-669$

ŠAKIĆ, V., VRSELJA, I. WERTAG, A.: RELATIONSHIP. path from our measure of substance abusing peers to inhalant use. Our measure reflected an average score on items regarding the number of friends who were at school under the influence of alcohol or some drug, selling drugs, used drugs (marijuana, ecstasy, cocaine, hashish, heroin, LSD etc.) and got drunk. It is possible that a more precise measure of drug abusing peers (i.e. number of friends that use inhalants) would yield different results in predicting inhalant use among our sample. Moreover, different developmental paths of sensation seeking and peers' importance for specific age group included in our sample might account as well for the unexpected results regarding personality factors, association with substance abusing peers and inhalants use we got. It is important to note that inhalant use, unlike other drug use, is most common among younger adolescents (i.e. 8th grade compared to 10th and 12th grades), and tends to decline as adolescents grow older (Johnston, O'Malley, Bachman, \& Schulenberg, 2009). In line with this, it is important to mention that sensation seeking increases between ages 10 and 15 , and declines or remains stable thereafter (Steinberg et al., 2008). On the other hand, Steinberg and Monahan, (2007) showed on a large US sample that peer importance, measured with resistance to peer influence, increases linearly between ages 14 and 18, while there is little evidence for growth in this capacity between ages 10 and 14. Indeed, Gardner and Steinberg (2005) demonstrated in an experimental study that adolescents aged 13 to 16 are more inclined to engage in risk taking than youths (18-22) and adults ( 24 and older), and the peer effects on risk taking and risky decision making were stronger among adolescents and youths than adults. Although these studies done by Steinberg and his colleagues did not include drug using, it is reasonable to assume that their findings are applicable in this setting as well, since drug using is a form of risk taking. Apart from nonsignificant indirect effects of sensation seeking and anger on lifetime inhalant use, our results have also shown that these two personality factors do not exert significant direct effect on lifetime inhalant use. Sensation seeking was expected to be related to inhalant use based on previous research (e.g., Howard, Walker, Walker, Cottler, \& Compton, 1999; Nonnemaker, Crankshaw, Shive, Hussin, \& Farrelly, 2011). For example, Howard et al. (1999) found that Indian youth inhalant users were high sensation seekers, and had more extensive deviant peer networks, while Nonnemaker et al. (2011) in a large sample of a longitudinal household survey found that higher reported levels of sensation seeking are associated with a significant increase in the odds of inhalant initiation among adolescents 
DRUŠ. ISTRAŽ. ZAGREB GOD. 22 (2013), BR. 4, STR. $651-669$

ŠAKIĆ, V., VRSELJA, I., WERTAG, A.: RELATIONSHIP.. in the USA. The reason for finding the nonsignificant direct effect of sensation seeking on inhalant use in our study might be the fact that inhalants are widely accessible to children. Moreover, unlike cannabis, inhalants are not illegal, and, unlike alcohol and cigarettes, minors can purchase them legally. Therefore, acquiring inhalants does not necessarily involve a high sensation seeking experience per se. Anger was also expected to be related to inhalant use based on previous research (e.g., Oetting, Edwards, \& Beauvais, 1988). Oetting et al. (1988) report that young inhalant users are likely to have more emotional problems than nondrug users or young marijuana users. Authors consider that these problems, particularly when they involve feelings of anger and alienation, increase the chances that they will identify with other youth who have similar feelings, form peer clusters, find a best friend or form a small gang that has a high potential for getting involved with drugs. Therefore, our findings could reflect the existence of other variables in predicting inhalant use among Croatian adolescents.

To our knowledge, this research is the first one to simultaneously study the relation of sensation seeking and anger in the explanation of both lifetime cannabis use and lifetime inhalant use. An additional contribution of this work lies in the fact that it studied whether direct effects of these two personality factors are dependent on gender. Nevertheless, some of its limitations have to be mentioned. First, our study is cross-sectional by nature, so we cannot make conclusions about the temporal order of the variables. It also employed one approach in examining the relationship between personality factors, drug use and gender. It is worthwhile mentioning that besides studying the relationship between gender and drug-conductive personality factors as they affect drug use, the relationship between gender and drug use as possibly mediated by personality differences can be studied as well (Brook, Whiteman, \& Cohen, 2000). The second limitation is related to the measure of lifetime inhalant use. Namely, this drug type is measured with only one question. Since inhalant use entails a broad number of substances (i.e. using glue, correction fluids, paint thinners or removers, gasoline, lighter fluids etc. to get high), employing a measure with a greater number of the aforementioned substances may be useful in gaining more precise information regarding risk and protective factors underlying inhalant use. Finally, our sample was not representative of the adolescent population. Nevertheless, our results yield both theoretical and practical implications. Theoretically, this study outlined the importance of both the direct and 
DRUŠ. ISTRAŽ. ZAGREB GOD. 22 (2013), BR. 4 STR. $651-669$

ŠAKIĆ, V., VRSELJA, I., WERTAG, A RELATIONSHIP.

indirect effects of sensation seeking, as well as direct effects of anger on adolescents' lifetime cannabis use. Regarding practical implications, these results can be used as a guideline in the construction and evaluation of preventive measures of drug use. For instance, targeting preventive measures to limit high sensation seekers to interact with substance abusing peers or to create more opportunities for high sensation seekers to engage in prosocial activities may act to suppress the potential for having interactions with peers that are favorable of drug use. In this respect, the approach taken in this study has significant potential in terms of developing more sophisticated and effective measures in adolescent drug use to the extent it will continue to guide future research in this field.

\section{REFERENCES}

Arnold, P., Fletcher, S., \& Farrow, R. (2002). Condom use and psychological sensation seeking by college students. Sexual and Relationship Therapy, 17(4), 355-365. doi:10.1080/1468199021000017209

Baron, R. M., \& Kenny, D. A. (1986). Moderator-mediator variables distinction in social psychological research: Conceptual, strategic, and statistical considerations. Journal of Personality and Social Psychology, 51(6), 1173-1182. doi:10.1037/0022-3514.51.6.1173

Brook, J. S., Whiteman, M., \& Cohen, P. (2000). Warriors and worriers: A longitudinal study of gender differences in drug use. NIDA Research Monographs, 271-284.

Buss, A. H., \& Perry, M. P. (1992). The aggression questionnaire. Journal of Personality and Social Psychology, 63(3), 452-459. doi:10.1037/00223514.63.3.452

Colder, C. R., \& Stice, E. (1998). A longitudinal study of the interactive effects of impulsivity and anger on adolescent problem behavior. Journal of Youth and Adolescence, 27(3), 255-274. doi:10.1023/A:102288 9202419

Donohew, L., Hoyle, R. H., Clayton, R. R., Skinner, W. F., Colon, S. E., \& Rice, R. E. (1999). Sensation seeking and drug use by adolescents and their friends: Models for marijuana and alcohol. Journal of Studies on Alcohol, 60(5), 622-631.

Dulčić, A., Ajduković, M., \& Kolesarić, V. (2003). Etički kodeks istraživanja s djecom [Ethical code of research with children]. Zagreb: Državni zavod za zaštitu obitelji, materinstva i mladeži. Vijeće za djecu Vlade Republike Hrvatske.

European School Survey Project on Alcohol and Other Drugs (2011). Substance Use Among Students in 36 European Countries. http://www. espad.org/Uploads/ESPAD_reports/2011/Extended_EMCDDA_2011 _ESPAD_Summary_EN.pdf $\bar{f}(20-09-2012)$

Gardner, M., \& Steinberg, L. (2005). Peer influence on risk taking, risk preference, and risky decision making in adolescence and adulthood: An experimental study. Developmental Psychology, 41(4), 625-635. doi: 10.1037/0012-1649.41.4.625 
DRUŠ. ISTRAŽ. ZAGREB GOD. 22 (2013), BR. 4, STR. $651-669$

ŠAKIĆ, V., VRSELJA, I., WERTAG, A.: RELATIONSHIP...
Gruber, J. (2001). Risky behavior among youths: An economic analysis. Cambridge: MIT Press. doi:10.7208/chicago/9780226309972.001.0001

Hampson, S. E., Andrews, J. A., \& Barckley, M. (2008). Childhood predictors of adolescent marijuana use: Early sensation seeking, deviant peer affiliation, and social images. Addictive Behavior, 33(9), 1140-1147. doi:10.1016/j.addbeh.2008.04.010

Hawkins, J., Catalano, R., \& Miller, J. (1992). Risk and preventive factors for alcohol and other drug problems in adolescence and early adulthood: Implications for substance abuse prevention. Psychological Bulletin, 112(1), 64-105. doi:10.1037/0033-2909.112.1.64

Hayes, A. F. (2013). An introduction to mediation, moderation, and conditional process analysis: A regression-based approach. New York: Guilford Press.

Howard, M. O., Walker, R. D., Walker, P. S., Cottler, L. B., \& Compton, W. M. (1999). Inhalant use among urban American Indian youth. Addiction, 94(1), 83-95. doi:10.1046/j.1360-0443.1999.941835.x

Johnston, L. D., O'Malley, P. M., Bachman, J. G., \& Schulenberg, J. E. (2009). Monitoring the Future national results on adolescent drug use: Overview of key findings, 2008. Bethesda, MD: National Institute on Drug Abuse.

Knyazev, G. G. (2010). Reward seeking as a predictor of drug use in youth: Effect of gender and social environment. The Open Addiction Journal, 3(1), 1-8. doi:10.2174/1874941001003010001

Needle, R. H., Su, S. S., \& Doherty, W. J. (1990). Divorce, remarriage, and adolescent substance use: A prospective longitudinal study. Journal of Marriage and the Family, 52(1), 157-169. doi:10.2307/352847

Newcomb, M. D., \& McGee, L. (1991). Influence of sensation seeking on general deviance and specific problem behavior from adolescence to young adulthood. Journal of Personality and Social Psychology, 61(4), 614-628. doi:10.1037/0022-3514.61.4.614

Nichols, T. R., Mahadeo M., Bryant, K., \& Botvin, G. J. (2008). Examining anger as a predictor of drug use among multiethnic middle school students. Journal of School Health, 78(9), 480-486. doi:10.1111/ j.1746-1561.2008.00333.x

Nonnemaker, J. M., Crankshaw, E. C., Shive, D. R., Hussin, A. H., \& Farrelly, M. C. (2011). Inhalant use initiation among U.S. adolescents: Evidence from the national survey of parents and youth using discrete-time survival analysis. Addictive Behavior, 36(8), 878-881. doi:10. 1016/j.addbeh.2011.03.009

Oetting, E. R., \& Beauvais, F. (1987). Peer cluster theory, socialization characteristics, and adolescent drug use: A path analysis. Journal of Counseling Psychology, 34(2), 205-213. doi:10.1037/0022-0167.34.2.205

Oetting, E. R., \& Beauvais, F. (1988). Common elements in youth drug abuse: Peer clusters and other psychosocial factors. In S. Peele (Ed.), Visions of addiction: Major contemporary perspective on addiction and alcoholism (pp. 141-161). New York: Lexington Books.

Oetting, E. R., \& Donnermeyer, J. F. (1998). Primary socialization theory: The etiology of drug use and deviance. I. Substance Use $\mathcal{E}$ Misuse, 33(4), 995-1026. doi:10.3109/10826089809056252 
DRUŠ. ISTRAŽ. ZAGREB GOD. 22 (2013), BR. 4 STR. $651-669$

ŠAKIĆ, V., VRSELJA, I., WERTAG, A : RELATIONSHIP.
Oetting, E. R., Deffenbacher, J. L., \& Donnermeyer, J. F. (1998). Primary socialization theory: The role played by personal traits in the etiology of drug use and deviance. II. Substance Use $\mathcal{E}$ Misuse, 33(6), 1337-1366. doi:10.3109/10826089809062220

Oetting, E. R., Edwards, R. W., \& Beauvais, F. (1988). Social and psychological factors underlying inhalant abuse. NIDA Monograph Series, 85, 172-203.

Oetting, E. R., \& Lynch, R. S. (2003). Peers and the prevention of adolescent drug use. In Z. Sloboda \& W. J. Bukoski (Eds.), Handbook of drug abuse prevention: Theory, science, and practice (pp. 101-128). New York: Kluwer Academic/ Plenum Publishers.

Preacher, K. J., \& Hayes, A. F. (2008). Asymptotic and resampling strategies for assessing and comparing indirect effects in multiple mediator models. Behavior Research Methods, 40(3), 879-891. doi:10. 3758/BRM.40.3.879

Resnick, M. D., Bearman, P. S., Blum, R. W., Bauman, K. E., Harris, K. M., Jones, J., Tabor, J., Beuhring, T., Sieving, R. E., Shew, M., Ireland, M., Bearinger, L. H., \& Udry, J. R. (1997). Protecting adolescents from harm: Findings from the National Longitudinal Study for Adolescent Health. Journal of the American Medical Association, 278(10), 823-832. doi:10.1001/jama.1997.03550100049038

Rolison, M. R., \& Scherman, A. (2002). Factors influencing adolescents' decisions to engage in risk-taking behavior. Adolescence, 37(147), $585-596$.

Rosenblitt, J. C., Soler, H., Johnson, S. E., \& Quadagno, D. M. (2001). Sensation seeking and hormones in men and women: Exploring the link. Hormones and Behavior, 40(3), 396-402. doi:10.1006/hbeh.2001.1704

Ručević, S., Ajduković, M., \& Šincek, D. (2009). Razvoj upitnika samoiskaza rizičnog i delinkventnog ponašanja mladih (SRDP-2007) [Development of Youth Self-Reported Delinquency and Risk Behavior Questionnaire (SRDP-2007)]. Kriminologija i socijalna integracija, 17(1), 1-96.

Scurlock, C. J. (2010). Effect of sensation seeking and perfectionism on stimulant use. Open Access Theses and Dissertations from the College of Education and Human Sciences. Paper 67. http://digitalcommons. unl.edu/cehsdiss/67 (01-09-2013).

Shrout, P. E., \& Bolger, N. (2002). Mediation in experimental and nonexperimental studies: New procedures and recommendations. Psychological Methods, 7(4), 422-445. doi:10.1037/1082-989X.7.4.422

Simon, R. W., \& Lively, K. (2010). Sex, anger and depression. Social Forces, 88(4), 1543-1568. doi:10.1353/sof.2010.0031

Spielberger, C. D., Johnson, E. H., Russell, S. F., Crane, R. J., Jacobs, G. A., \& Worden, T. J. (1985). The experience and expression of anger: Construction and validation of an anger expression scale. In M. A. Chesney, \& R. H. Rosenman (Eds.), Anger and hostility in cardiovascular and behavioural disorders (pp. 5-30). New York: Hemisphere.

Steinberg, L., \& Monahan, K. C. (2007). Age differences in resistance to peer influence. Developmental Psychology, 43(6), 1531-1543. doi:10. 1037/0012-1649.43.6.1531 
DRUŠ. ISTRAŽ. ZAGREB GOD. 22 (2013), BR. 4, STR. $651-669$

ŠAKIĆ, V., VRSELJA, I., WERTAG, A.:

RELATIONSHIP.
Steinberg, L., Albert, D., Cauffman, E., Banich, M., Graham, S., \& Woolard, J. (2008). Age differences in sensation seeking and impulsivity as indexed by behavior and self-report: Evidence for a dual systems model. Developmental Psychology, 44(6), 1764-1778. doi:10.1037/a0012955

Swaim, R. C., Oetting, R. W., \& Beauvais, F. (1989). Links form emotional distress to adolescent drug use: A path model. Journal of Consulting and Clinical Psychology, 57(2), 227-231. doi:10.1037/0022-006X .57.2.227

Thomas, S. P., \& Williams, R. L. (1991). Perceived stress, trait anger, modes of anger expression, and health status of college men and women. Nursing Research, 40(5), 303-307. doi:10.1097/00006199-1991 09000-00022

Vrselja, I. (2011). [Association with Deviant Peers Questionnaire]. Unpublished raw data.

Yanovitzky, I. (2005). Sensation seeking and adolescent drug use: The mediating role of association with deviant peers and pro-drug discussions. Health Communication, 17(1), 67-89. doi:10.1207/s15327 027hc1701_5

Yanovitzky, I. (2006). Sensation seeking and alcohol use by college students: Examining multiple pathways of effects. Journal of Health Communication, 11(3), 269-280. doi:10.1080/10810730600613856

Zuckerman, M. (1994). Behavioral expressions and biosocial bases of sensation seeking. Cambridge: Cambridge University Press.

Zuckerman, M. (1996). The psychobiological model for impulsive unsocialized sensation seeking: A comparative approach. Neuropsychobiology, 34(3), 125-129. doi:10.1159/000119303

Zuckerman, M., Eysenck, S., \& Eysenck, H. J. (1978). Sensation seeking in England and America: Cross-cultural, age and sex comparisons. Journal of Consulting and Clinical Psychology, 46(1), 139-149. doi:10. 1037/0022-006X.46.1.139

Zuckerman, M., \& Kuhlman, D. M. (2000). Personality and risk-taking: Common biosocial factors. Journal of Personality, 68(6), 999-1029. doi:10.1111/1467-6494.00124

\section{Odnos između ličnosti i upotrebe droga kod adolescenata: učinci vršnjaka koji zloupotrebliavaju droge i spola}

Vlado ŠAKIĆ, Ivana VRSELJA, Anja WERTAG

Institut društvenih znanosti Ivo Pilar, Zagreb

Cilj ovog rada bio je istražiti imaju li traženje uzbuđenja i ljutnja direktan i/ili indirektan učinak na cjeloživotnu upotrebu kanabisa i inhalanata kroz vršnjake koji zloupotrebljavaju droge. Također, cili je bio istražiti ovise li direktni učinci ovih dviju osobina ličnosti o spolu. Analizirani podaci prikupljeni su 2012. godine na 394 učenika (186 dječaka, 193 djevoj- 
DRUŠ. ISTRAŽ. ZAGREB GOD. 22 (2013), BR. 4 STR. $651-669$

ŠAKIĆ, V., VRSELJA, I. WERTAG, A

RELATIONSHIP. čice, a 15 učenika nije naznačilo spol), u dobi od 15 do 17 godina. U slučaju cjeloživotne upotrebe kanabisa,

medijacijske analize pokazale su značajan indirektan učinak traženja uzbuđenja na ovu vrstu droge kroz vršnjake koji zloupotrebljavaju droge. Isto tako, pokazalo se da traženje uzbuđenja i liutnja imaju i direktan učinak na upotrebu ove vrste droge, no neovisno o spolu. U slučaju cjeloživotne upotrebe inhalanata, dvije osobine ličnosti nemaju ni indirektan ni direktan učinak na upotrebu ove droge. Ovi direktni učinci ne ovise ni o spolu. Podaci prikazani u ovom radu rasvjetljavaju rizične putove primjene kanabisa $\mathrm{i}$ inhalanata te razmatraju moguće razlike u tim rizičnim putovima.

Ključne riječi: traženje uzbuđenja, ljutnja, vršnjaci, kanabis, inhalanti 